\title{
12 Public accountability within transnational supply chains: a global agenda for empowering Southern workers?
}

\section{Kate Macdonald}

In recent years, one of the central claims promoted by critics of "globalization" has been that the existing system of global economic governance is being undermined by the cmergence of "accountability deficits." According to this widespread view, the expanding power of multinational companies to influence the lives of workers in the global South, in the absence of adequate accountability mechanisms, is leading to increasing exploitation of Southern workers. Partly in response to such perceptions, a range of non-state actors have begun to explore new strategies that attempt to hold companies within transnational supply chains directly accountable for their impact on the lives of workers. In this context, both the seriousness of existing accountability deficits, and the effectiveness of non-state initiatives designed to confront them, remain the subject of widespread debate.

This chapter presents an analysis of these debates with reference to a case study of workers in Nicaraguan garment factories, and the production chains that connect them into the global structures of the garment industry.' It maps current changes to institutions of governance and accountability within the garment industry, and evaluates the impact of these changes upon the "empowerment" of Southern garment workers." The garment industry offers an ideal case for exploring transformations of public accountability within transnational economic structures, since it is both extensively globalized and highly politicized. Its transnational supply chains connect some of the world's poorest

\footnotetext{
This particular case is used here simply for illustrative purposes. For a more detailed accoun of the dynamics of thange within structures of power and acenutability in the global garment industry, and of the examples refered to in the present discussion, sec Macdonald (2004).

* The concept of empowement is claborated below. It provides the conceptual francwork through which the implications for Southern workers of transformatimes in glothil govemance are then analyzed and evaluated.
} 
workers with affluent and powerful consumer markets and corporate entities in the global North, and it has been prominently politicized in recent years by coalitions of non-state actors promoting a global agenda of "core labor standards." The present analysis draws on field research conducted at all levels of the supply chain, including the production phase in Nicaragua, consumer markets in the US, and the actions of investors and civil society advocates spanning the US, Europe, and East Asia.

The chapter begins by reviewing the central concepts deployed in the subsequent analysis; it then maps the broad patterns of change currently evolving within institutions of public accountability in the global economy. The discussion takes as its point of departure the structures of the statebased governance system and the "binary" relations of accountability that underpin it and describes how these structures are being challenged by the emergence of new agendas, which I characterize as "transformative" and "external" accountability. The extent to which these different forms of accountability are serving to empower Southern workers is then evaluated, drawing on examples from Nicaragua-based garment supply chains. It is concluded that in order to institutionalize the empowerment of Southern workers more effectively within transnational production chains, it will be necessary to develop a more complex "plurilateral" approach to the design of global institutions of public accountability.

\section{Governance and public accountability}

\section{What is acenmability, and why does it matter?}

The central concept underpinning the present discussion is that of "accountability," which 1 define as a property of an institutionalized relationship in which the exercise of power by one set of actors is constrained subject to some requirement of responsizeness to those over whom their power is exercised. This conception of accountability can be usefully decomposed into two functional dimensions: transparency in the exercise of power (entailing either formal reporting requirements or some alternative information transmission mechanism), and cnforcubility of the principle of responsiveness (generally via provision of some means by which sanctions can be imposed on powerholders in cases where their behavior breaches some common understanding of "acceptable" standards) (Woods, 2000; Keohane and Nye, 2001; Keohane, 2002; Newell and Bellour, 2002). ${ }^{3}$ While accountability

In the complex institutional environments that are necessary to facilitate global structures of production, accountability relationships can involve divisions of labor in 
relationships can exist between the bearers and objects of power within any institutionalized relationship, debates surrounding "accountability deficits" in institutions of global governance are concerncd more narrowly with accountability for the excreise of what is considered to be "public" power. The following analysis therefore focuses specifically on the concept of "public accountability." I use this term to refer to answerability for the exercise of power over "publicly relevant" outcomes, understood as that range of outcomes in which shared or competing interests are significantly implicated."

Structures of accountability provide those actors who are subject to the exercise of power with an institutionalized means of redress through which they can express dissatisfaction with the actions of powerholders. Such structures can therefore be understood as comprising an institutionalized form of countevailing power. Considered in this light, the concept of accountability makes little sense unless it is analyzed with reference to the structures through which primary sources of public power are distributed. Publicly relevant power is traditionally conceptualized as being exercised and regulated through state institutions; however, much of this chapter will focus on structures of public power and accountability that are emerging beyond this state-centered realm. The concept of "governance," referring to the processes through which an organization or society steers and coordinates itself, offers a framework through which the distribution of such broader sources of power can be analyzed (Rosenau, 2000; Scholte, 2002)."

which those who are cntitled to demand answers from puwerholders are net necessurity the same actors as those in charge of deternining and imposing penaties (Gocte and Jenkins, 2002). For cxample, information regarding a firm's axtisitics whoh is exposed by an NGO or provided to 2 regularory agency can, when made public, stmulate the imposition of a sanction in the form of a consuncer boyent. Some important implications of these pluralistic divisions of labor within accountubility seructures are discussed below.

This definition of publicly relevant power encompasses both a liberal concem for power that constrains other social actors" autonomy (Kowanc, 2002; 16de, 2004), and an understanding of public power as that advancing a general or commen interest. The sphere of public interest is thus defined according to the extent to which interests are interdependent cither common or competing. Of course, whar we define as hoing publicly relevant is itself politically contested, and dominant relations of power will be reflected in its construction (Cuther, 2002, p. 34).

"I therefore use the term "gowernance" w refer to activities backed by shared geals that do not necessarily derive from legal and homally prescribed responsibilities or rety on police powers to attain compliance (Snouts, 1908: Soker, 1908). Instead, governance operates through a combination of institutions, organizatons, and networks in which publicly relevant power is exercisct not only through formally stnetionct system of law, but also through the construction of meanings, identitics, and noms, and through diffuse as well as centralized enfortement mechanisms (Rosenau, 19092; Rosenatu. 200); Deromasi, 2002; Lipschutz and Fogel, 2002; Woods, 2002). 
Institutions of governance and accountability can then be understood as mutually constitutive dimensions of an overarching institutional complex that I refer to as a "governance system." The structure of accountability relationships in a governance system is of central importance in determining the way in which roles, responsibilities, and powers are distributed between actors, and the mechanisms through which the excrcisc of power is constrained. "Put simply, accountability mechanisms are designed to equilibrate power and responsibility within a governance system. This requires first that power and responsibility are distributed such that identifiable actors have responsibility for publicly relevant outcomes, and those with responsibility also have the capacity to steer and regulate these outcomes. Second, it requires that a degree of countervailing power is placed in the hands of those over whom the primary power is wiclded, thus enabling the responsibilities of powerholders to be effectively enforced. By facilitating and constraining the exercise of power, the operation of accountability mechanisms is often crucial in determining patterns of "winners" and "losers" that emerge within the governance system as a whole.

Why is the wisting state-contord system of acomintability and goremance being challonged by new agendas of uciomitability?

To make sense of how and why new forms of global accountabilities are emerging, we must first identify the ways in which changes in the global political economy are challenging the effectiveness and legitimacy of the preexisting state-based system of governance and accountability. Within this existing system, we tend to take for granted the distribution of power and accountability through what I refer to as a binary structure, in which responsibilities for publicly relevant outcomes are assigned primarily to centralized state institutions, and public accountability is then constructed as a binary relationship between a territorially constituted state and members of its constituent "public.", There is widely shared understanding and agreement regarding the core principles through

A simikar point is made by Newell and Bellour (2002)

The logic of this binury acountability soructure is not incompatible with the fact that individual companies also widd direet power over "publicly relevant" outcomes experienced by workers; cleaty, such power has always been a feature of capitalist cconomic systems. Rather, this lengic assumes that steh forms of corporate power are framed and sustimed by the overarching regulatory power of the state, and thus that the fowtion within the state of centralized rexponsibility for profecting working conditions is matched by state capacity to steer and regulate outcomes. 
which public power and associated responsibilities are thus distributed, in which the exercise of countervailing power by constituent members of the territorial public (both individuals and collective non-state actors) functions to legitimize privileged sources of state power by institutionalizing their limits, subject to an expression of consent by the governed. Because the legitimacy of prevailing power distributions are thus conditional upon the operation of these binary accountability relations, such mechanisms of "legitimizing accountability" serve to strengthen and reproduce the existing governance system, maintaining its stability over time.

Because these binary relations are constructed between a tomitorially bounded public and state, the ongoing legitimacy of existing accountability structures is contingent upon the premise that power to determine publicly relevant outcomes remains subject to territorial control. However, within the global garment industry the legitimacy of this state-centered governance system is being undermined by the increasing exercise of direet power over Southern workers by extraterritorial corporate actors controlling global supply chains. Within these "buyer-driven" chains, Northern brands and retailers are able to control marketing and design activities, which in turn enables them to wield extensive power over decision-making throughout the global chain (Gereffi, 1999).

According to the principles of the state-centered governance system, the direct power exerted by Northern brands and retailers over Southern workers should be regulated by each state within which affected workers are located. In fact, the high degree of territorial mobility of these buyerdriven production chains undermines the effectiveness of such statebased regulatory structures, resulting in misalignment between systemic distributions of responsibility and outcome-producing power that has increasingly undermined the capacity of national governments to discharge effectively the regulatory responsibilities that continue to be vested in them.

The weakened capacity of the state to discharge its assigned responsibilities as a result of these changes in the global economy is clearly exemplified by the case of Nicaragua. While Nicaragua's constitution and labor laws codify extensive safeguards of working conditions and other entitlements of workers (CENIDH, 2003, p. 16), the Nicaraguan government's performance in monitoring and enforcement of these rules has demonstrated significant weaknesses. Ineffective state enforcement can be attributed primarily to a lack of resources and penalties available to inspectors within the Ministry of Labor. According to the Ministry's own records, they have carried out only seventy-five inspections in the country's sixty-two free-trade-zone factories over a period of four years, despite rules requiring periodic visits (CENIDH, 2003, 
p. 62). The penalties themselves are also very weak, with the maximum fine payable by companies that violate the labor laws being only 10,000 cordobas (approximately US\$630). This absence of strong coercive mechanisms dilutes the impact of the enforcement regime, even in those cases in which penalties are imposed."

This failure to effectively enforce state-based labor standards, in particular the absence of adequate penalties, can to a large extent be attributed to a lack of political will at the highest level of Nicaraguan government, as illustrated by the National Assembly's fallure to pass a bill initiated in 1999 by the women's organization Maria Elena Cuadra; this organization had sought to have tax exemptions made conditional upon compliance with labor standards - a change that would have provided a more strongly cocrcive mechanism to enforce labor laws (CENIDH, 2003, p. 15). Such lack of political will is in turn attributable at least partly to the direct pressure placed on governments by investors, who enjoy considerable mobility with respect to production locations due to the labor-intensive nature of assembly production, and who openly express their preference for investing in countries where labor legislation will not cause them "problems." investors is exerted upon host governments not only in relation to the overall legislative framework of the labor law, but also in the context of specific labor disputes.

'This increasing misalignment between regulatory power and distributions of responsibility is often characterized as reflecting a shift in power from "states" to "markets" or "corporations," each conceived as a generic category. However, analysis of the garment industry suggests that in fact much of the shift in regulatory power is not away from the state-hased system as a whole, but rather from states in which production and workers are based, and towards consumer states (and to a lesser extent, investor states) located higher up the chain of buyer-driven production. At a structural level, this reflects a redistribution of power towards the governments of countries in which are located those stages of economic activity that are characterized by greater barriers to the exit of capital. "Shifts of power between individual states that are positioned

*These inspection requirenents are outined in Article 14 of the Ministry's Reglamento de

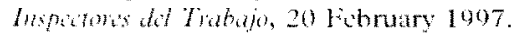

"Sourc: Intwricw by the author at MITRAB, Managua, 13 Novenber 2003.

1"3 Source: Intervicw by the atuthor at Nicn Hsing head office, Tapei, 10 March 2004.

"This is consistent with the idea that deregulation of capital movements has "altered the

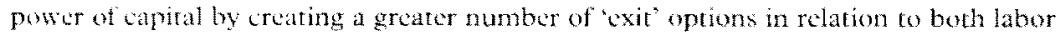
and the state" (Held, 2000, p, 300; Strange, 2000; Koenig Archibugi, 2004). However, it gexs further in that it highlighes the direct correlation between the magnitude of this 
differently within global production chains are less commonly identified as a source of emerging accountability deficits than are shifts in power between "states" and "corporations." "However, such an analysis draws attention to the important fact that when we speak of "powerful actors" being unaccountable to the workers whose lives they affect, this should be understood as referring not only to extraterritorial corporate actors, but also to extraterritorial states.

This point is illustrated by the processes through which the wages and working conditions experienced by Nicaraguan garment workers are directly influenced by the priorities and decisions of investor and consumer states. "Investor states retain some ability to exert leverage over outgoing garment investors, often by placing conditions on the provision of assistance. For example, the Taiwanese government channcls assistance to garment investors through its "Plan to Subsidize Industries Investing in Diplomatically Tied Countries," which supports garment companies investing in countries that recognize Taiwan's sovereign status, such as Nicaragua; similarly, the US government provides assistance to foreign investors via the Overseas Private Investment Corporation (OPIC). Both US and Taiwanese decision-makers consistently choose to deploy such support to promote nationally defined interests, rather than to defend the labor standards of workers outside their own territories. The Taiwanese subsidies take no account of a company's record on labor standard compliance (Nee, 2002), and while assistance through OPIC is nominally conditional upon the host country being in compliance with internationally recognized worker rights, ${ }^{14}$ in reality this condition is applied with considerable discretionary bias shaped by prevailing US cconomic and foreign policy considerations (Méndez and Koepke, 2001).

Because consumer markets represent the only component of the global commodity chain that cannot be territorially relocated, sovereignty over territory in which final consumer markets are located bestows regulatory power that is not eroded by the mobility of global

effect and the position of a given state and force within the globally disaggregated production process.

12 A notable exception is Keohane (2002), who places great emphasis m the lack of accountabilizy of "powerful" states.

13 Acknowledgment of the importance of decisions taken by states other than the one in which the affected workers are located reflects the idea that "decisions taken by representatives of nations and nation-states profoundly affect citizens of other mationstates - who in all probability have had no opportunity to signal consent or lack of it" (Hold, 1095, p. 139).

1t See www epic gov. 
capital. Accordingly, the greatest regulatory power is structurally located at the level of consumer states, which in the case of Nicaraguan garment production means the US government, since almost all garments produced in Nicaragua's free-trade zones are destined for US consumer markets. Although the US has a range of unilateral policies linking imports to labor standards, ${ }^{15}$ such regulations, as with labor provisions within OPIC, are administered through political processes in which protectionist or broader foreign policy objectives are generally accorded higher priority than the protection of foreign workers. Thus, although the position of consumer and (to a lesser extent) investor states gives them some capacity to regulate wages and working conditions of Southern workers within transnational supply chains, responsibilities to defend labor standards are exclusively constructed at the level of states in which workers are territorially located. This generates a disjuncture within the global political system, which contributes to the increasing ineffectiveness of state-based structures of governance and accountability in discharging the responsibilities they have been assigned for the protection of working conditions in the global South.

\section{Challenges and transformation to the state-based system of governance and public accountability}

\section{Acconitability direted to actors beyond the state}

These structural weaknesses within the traditional state-based governance system have contributed to the increasingly widespread view that the current system is failing effectively to regulate the impact of transnational corporate actors upon the lives of Southern workers. Accordingly, public accountability claims are being directed towards powerful actors beyond the centralized apparatus of the state: in particular, towards powerful "corporate" actors. Goetz and Jenkins (2002) identify this shift away from a narrow conceptualization of accountability as relating exclusively to the accountability of public sector institutions, and argue that a broader accountability agenda has been building momentum in recent years:

The failure of democratic institutions and the decline of national sovereignty have combined to generate pressure for new ways of making powerful actors,

\footnotetext{
The mow motatis among these are the Generalized System of Preferences, the Caribbean Basin Initiative, bans on imports of goods produced using prison labor or forcu child labor (Tingas, 2001), as well as brouder forms of "diplomacy" conducted through the International I ahor Aflairs OMee and the Special Representative on I abos Affairs.
} 
within and beyond the state, accountable for the impact of their actions on pon people... The result has been the emergence of "The New Aceountability Agenda". Existing mainly in fragments of conceptual innovation and practical experiment, the basic features of this agenda are nevertheless increasingly visible. (Goetz and Jenkins, 2002, pp. 3-4)

Such new agendas of accountability represent a broad challenge to deeply established ways of conceptualizing and institutionalizing power, responsibility, and accountability. As new agendas develop, they are contributing to the creation of more layered and composite structures of accountability that incorporate not only the binary structures of legitimizing accountability discussed above, but also what 1 refer to as "transformative" and "external" accountability, both of which are elaborated in greater detail below.

\section{Transformative accountability}

I use the term "transformative accountability" to describe those practices that have emerged, as actors secking to transform the existing system reject the core principles through which power is distributed and legitimized within the existing governance system, demanding instead that institutions of power and accountability be structured in accordance with a redefined set of principles. In contrast to practices of "legitimizing accountability" described above, transformative accountability demands function to delegitimize the existing governance system, and thus to contest the authoritative basis of existing structures of power. Transformative accountability claims thercfore signal the deviat of consent, not just to particular acts of power but to the fundamental structure of institutions through which power is distributed and legitimized.

Those issuing transformative accountability demands do more than challenge the legitimacy of the prevailing system. They also attempt to hold powerful actors accountable to the rules of a transformed governance system that does not yet formally exist. Under such circumstances, it is usual for powerholders to be unwilling - at least initially to participate in these new accountability relations by voluntarily providing information or accepting sanctions. Development of functional accountability mechanisms in the absence of the consent of powerholders therefore requires the construction of independent networks to facilitate the transmission of information regarding the activities of powerful actors, as well as independent mechanisms through which sanctions can be imposed unilaterally upon those powerholders who violate specified transformative principles. The imposition of these new accountability mechanisms thus contributes to the construction of 
a transformed system - both by directly forcing changes in the activities of targeted actors, and by reshaping constitutive discourses in ways that characterize prevailing power structures as illegitimate. These processes thereby contribute to developing a broader "public" in which norms, identities, and beliefs adapt to a transformed set of principles. ${ }^{16}$ In this way, the continued imposition of transformative accountability demands gradually opens new political spaces in which transformed institutions of governance can be imagined, constructed, and legitimized.

The "anti-sweatshop" campaigns that emerged within the global garment industry during the 1990 s provide a clear illustration of the mechanisms through which agendas of transformative accountability have been advanced. Through such campaigns, networks of human rights and labor advocates have attempted to improve working conditions and raise wages for workers in developing countries via a series of publicity campaigns directed towards "powerful" clothing brands and retailers in the United States and Europe. ${ }^{17}$ One commonly employed strategy has been the exposure of abuses within specific factories (a tactic sometimes referred to as "naming and shaming"), drawing on individual cases to support broader campaigns. In Nicaragua, for instance, the National Labor Committee in late 1997 launched a consumer campaign directed against Walmart, Kmart, and JC Penny via a documented "exposé" of conditions within Nicaraguan factories, screened on the US Hard Copy television program (Elliott and Freeman, 2000). ${ }^{18}$ Anti-sweatshop campaigns are also commonly based on the "international solidarity campaign" model, in which international "solidarity" networks comprised of non-state actors such as labor unions and NGOs are formed to support the demands of local unions in specific factories. A clear example of this is the campaign launched in 2001 in support of workers at the Taiwanese-owned Chentex factory in Nicaragua's Las Mercedes Free Trade Zone (Macdonald, 2004).

In launching such campaigns, non-state actors reject the traditional claim that regulation of labor standards is the exclusive responsibility of the governments of producing countries, pointing to the erosion of the regulatory capacity of such governments in the face of internationally mobile capital. Instead, they demand that companies be held directly accountable for the impact of their activities upon Southern workers,

\footnotetext{
"1 use the term "principle" in the sense defined by Braithwate and 1) rahos (2000).

17 (of forry-three LS-based groups identificd by Elliot and Freeman (2000) as working on sweatshop issues, just over half were formed in the $1990 \mathrm{~s}$, and noarly 80 percent have existod only since 1980 . Harrison and Scorse (2003) similarly document a 400 percent increase in the number of newspaper articles fecusing on sweatshop activities during the $90 \mathrm{~s}$.

is Sesw sweatshopwatch, arg/swatch/headlines/1997/nica deco7. hmol.
} 
framing their demands within principles of "core labor standards," "universal human rights," and "opposition to corporate power." Transformative demands thereby seek to reconstruct fundamental roles and responsibilities in ways that delegitimize existing arrangements in which a range of private sector actors wield important forms of publicly relevant power without accepting associated public responsibilities. They then demand that "private" actors should accept increased responsibility for the well-being of Southern workers within the transnational supply chains that they control. ${ }^{\text {[? }}$

Imposition of these new accountability demands has required the groups that issue them to construct mechanisms via which information can be transmitted and sanctions imposed without the consent of the companies concerned. In the short term, increased consumer awareness and concern regarding working conditions in offshore factories facilitates the strategic mobilization of consumer action, and its deployment as an independent coercive weapon able to be wielded in support of campaigners' demands. ${ }^{20}$ Such sanctioning mechanisms operate both through direct consumer boycotts, and through decper processes of socialization manifested as broader reputational damage to company brands. ${ }^{21}$ The significant sanctioning power generated by such strategies is illustrated by the fact that many companies participating in Nicaraguabased production chains reported that damage to their reputation represented a greater threat than the primary state-based sanctioning mechanism - that is, government-imposed fines.

The fines are very small and aren't really a big issue - the muen bigger concern is the bad image of the company that being given a fine produces, and the impression of not complying with the law of the counury. This is the real threat. For us Nien Hsing is a big company, and our reputation is very important. The fine doesn't worry us; rather it is being colored with the label of being a violator of rights. It is the prestige and not the money that we are worried about."

19) In many cases, however, their discourses are constructed in offorith to any shift in the focation of public power, with many argung that hoth responsibitig and pewer should deally remain with the state. To this extent, these challenges ta dentimes and responsiblities associated whth the categories of public and private are jeguded by some as a second-bust solution.

2t: "The importance of reputational effects is reflected in the statcment in 100 - by the then

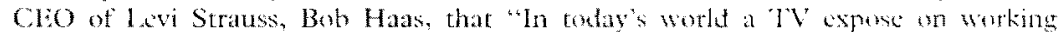
conditions can undo years of effort to build hrand boalry" (Jenkins, 2001, p. T).

21 Reputation is important not only with respect to conectud consumess, but also, regarding a range of husiness relations on the production side, including relations with current and potential employecs, business partners, and gosernment (Hanter, 201) Ruggia, 2001).

32 Interview by the author at Chih Hsing, Managual, + Novenber 2003 
Senior government officials appeared very conscious of this reality, seeking to harness non-state sanctioning mechanisms in support of their oun laws in cases where firms were repeatedly failing to comply with state regulations.

In reality, what we have to do is have someone senior ring them up and threaten them with what will happen if they don't comply: we say that we're going to pass the information about what is going on in their firms on to the media. They are very scared of this, much more than of the fines, so then they can be made to comply. ${ }^{23}$

In these ways, anti-sweatshop campaigns have constructed independent information transmission and sanctioning mechanisms through which powerful corporate actors can be pressured to accept increased responsibility for their impact upon the well-being of Southern workers. The transnational solidarity networks formed to support factory-based campaigns have provided further direct mechanisms through which information can be deployed and sanctions imposed in support of these transformative demands. The solidarity campaign based around the Chentex factory was able to exercise countervailing power by deploying the communicative and coordinating capabilities of their transnational networks to construct complex webs of influence that exerted pressure at strategic nodes of decision-making power. Within the private sector sphere, network participants in each country excrted pressure on the companies based in their territory, utilizing the mass media where possible. In Taiwan, the participating coalition of labor activists (the Taiwan Solidarity for Nicaraguan Workers) exerted pressure on the Taiwanese owner of the Chentex factory (the Nien Hsing consortium) by protesting outside the stockmarket and at the company's annual meeting. In Nicaragua, the Sandinista-based Chentex union placed direct pressure on local management via widespread protests and strikes. In the US, labor campaigners organized consumer boycotts and protests at retail outlets across the country, directed against major clients of the Chentex factory. Pressure was thereby exerted directly at each major point of decisionmaking within the global production chain, in the hope that pressure at the higher levels would be passed down to the factory level via the chains of command internal to the supply chain. There is evidence that this strategy functioned unevenly, but with considerable effectiveness.

The unions called CEOS of our customers at 2 in the moming to bother them and so then they called us and sad settle it down... The brands were under lots 
of pressure and were very concerned about their reputation - they said to us that we had to settle down the problem or they would give our orders to others... Some other brands were more supportive though, and said just ignore it. Different brands responded differently. ${ }^{21}$

While the vast majority of anti-sweatshop campaigns have directed their delegitimizing campaigns primarily towards corporate powerholders, in some cases, such as that of Chentex, solidarity campaigns have also placed coordinated pressure on the powerful, extraterritorial, investor, and consuming states, demanding that they also must accept responsibility for the conditions of Southern workers. In the case of Chentex, pressure was placed on individual members of the US Congress, who in turn signed letters of protest addressed to both President Clinton and the Taiwanese President. ${ }^{25}$ Labor groups also pressured the US Trade Representative to write to the Nicaraguan Minister of Foreign Affairs, warning that Nicaragua's Caribbean Basin Initiative preferences might be threatened if the dispute was not resolved. ${ }^{20}$ In addition, a legal action was launched in the US against Nien Hsing under the Alien Tort Law, alleging violations of the human rights of Chentex workers. ${ }^{27}$ Various forms of pressure were brought to bear in Taiwan: labor groups placed pressure on the state-owned Labor Insurance Fund, which owns about 5 percent of the shares in Nien Hsing; they also placed pressure on the Ministry of Foreign Affairs, suggesting that assistance provided through the "Plan to Subsidize Industries Investing in Diplomatically Tied Countries" should be denied to companies violating labor standards in offshore factories (Nee, 2002); further, a parliamentary hearing on the conflict was held in the Legislative Yuan. ${ }^{24}$ Nicaraguan unions attempted to place pressure on the Nicaraguan Ministry of Labor, and utilized judicial proceedings to challenge the union-busting activities of

2. Interview by the author at Nixn Hsing head offec, Tapei, 10 March 2004.

25 lerters signed by sixty-four members of Congress were sent to both Presidete Clinton and the Tawanese Predident Chen Shuibian an 21 July 2000 , following a delegarion to Nicaragua led by Congressnan Sherrod l3rown.

2* US Trade Representative Charlene Barshetsky wrote the Nicaraguan Minister of Foreign Affairs Eduardo Montealezre on 3 Octobur 2000 expressing concern regarding rights violations in the Chentex and Mil Calotes facteries, and stating that "fidure to acheve an improvenent in this situation could place part or all of Vicaragua $\mathrm{C}$ CIPA trade preterenees in jeopandy".

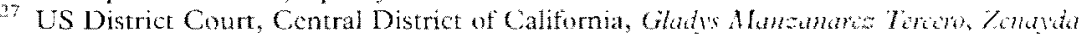

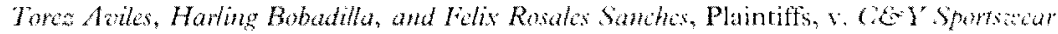
Inc, Nien Hsmg Textile Co. Ifd. and Chentex Gammus, SA. Defendents, Case No CV $00-12715 \mathrm{NA}(\mathrm{Clx})$

2k E-mail from Professor Hsin-Hsing Chen to US mombers of the solidarity network, 1 April 2000, "Report on Tawan Legislative Yuan Hearing on the Chentex Case." 
Chentex management. They also appealed to the $1 \mathrm{LO},{ }^{29}$ attempting to deploy its formal complaints mechanisms to place additional pressure on the Nicaraguan government. By coordinating action at these multiple, state-based pressure points, in addition to targeting multiple decisionmaking nodes within transnational production chains, anti-sweatshop campaigners attempted to mobilize their independent information transmission and sanctioning capabilities to demand that not only powerful companies but also extraterritorial states must accept greater responsibility for the well-being of Nicaraguan workers.

\section{Lixtemal accomability}

Over time, as transformative accountability claims have continued to be directed towards new categories of powerful actors, some of these powerholders have begun to respond, at least superficially, to the transformative challenge. As they have begun to acknowledge increased responsibilities for their impact on an expanded set of "external" stakeholders, such actors have established a range of institutional mechanisms through which limited forms of answerability to certain categories of such stakeholders can be facilitated. These institutions, which I refer to as institutions of extemal accountability, therefore represent the partial institutionalization of transformative demands in which previously unacknowledged responsibilities and accountabilities are constructed. 30

The emergence of external accountability mechanisms is often characterized as offering a potential solution to the emergence of accountability deficits with in the existing system of global governance. However, the concept of external accountability - defined by Keohane (2002, p.14) as "accountability to people outside the acting entity, whose lives are affected by it" - remains underspecified in two crucial ways. "First, the attempt to present a coherent definition of external accountability relations based on membership of an "acting entity" serves to circumvent rather than rusolve the key source of the accountability deficit: that is, the contestation of social and political boundaries, and thus the

"Complaints against the Gowernment of Nicaragua presented by the Jose Beniro Escobar Trade Lnion Contederation of Workers and the International Textile, Garment and Leather Workers' Federation," Repont No 324, Cases Nos 2092 and 2101.

"The concept of "external accountability" is very close to the more commonly used "stakeholder accountability."

"Thin does not retlect a weakness specitic to Keohane's definition; rather, it reflects decper limitations of the concept of external acenunability, and of the set of institutional practices with which the coneept has been associated. 
underlying disagreement regarding who or what constitutes the "acting entity" in the first place. Discourses of external accountability have emerged precisely beeause the boundaries between multiple and overlapping social and political "entities" are not clear or agreed, so incorporating this term into the definition as though its meaning were self-evident serves not to clarify but simply to obscure the underlying systemic conflict from which the concept of "external accountability" has emerged.

Second, this definition in itself tells us nothing about appropriate normative criteria of "affectedness," on the basis of which we might seek to define the boundaries of new forms of external accountability. While more extensive responsibilities to external stakcholders are acknowledged, there is no agreed definition of who new relationships of responsibility and accountability should be constructed between, or precisely what these responsibilities should entail. In practice, the various corporate practices that are subject to constraint via mechanisms of "external" or stakeholder accountability therefore emerge as a product of pragmatic political compromise, and remain largely discretionary in scope and substance. The concept of external accountability is useful insofar as it implies some acknowledgment of the problem of contested legitimacy of prevailing power relations. However, without resolution of the underlying sources of normative contestation, external accountability cannot in itself constitute a solution,

The implications of such ongoing normative contestation for the kinds of institutions and practices that have emerged are reflected in the most prominent example of external accountability structures within the garment industry: codes of conduct. These codes have emerged as a key means by which firms have responded to the sustained pressure exerted on them by the transformative accountability demands of the antisweatshop movement. A diverse range of models have been developed, including "corporate" codes of conduct (the most common varicty in Nicaraguan garment factorics), industry association codes such as Worldwide Responsible Apparel Production (WRAP), multi-stakeholder codes such as that of the Fair Labor Association (HLA) and NGO-driven codes such as SA8000. A range of monitoring systems have also been developed to enhance the effectiveness and credibility of these codes, including private sector monitoring systems conducted by companies such as PricewaterhouseCoopers, monitoring systems operated in-house by retailers, brands, or their contracted trading companies, and independent monitoring procedures conducted by local NGOs.

By implementing a code of conduct, firms institutionalize within this formal structure some acknowledgment of the power that they alrcady 
wield within transnational supply chains and, at least nominally, they accept increased responsibility for the conditions of workers participating within these structures. Because the codes have emerged at least partially in response to anti-sweatshop campaigns, they institutionalize to some extent the transformative demands of extemal stakeholders. However, the primary motivation of the firms establishing such codes is to respond to the specific demands that they perceive as most strongly delegitimizing their activities in the eyes of the Northern consuming public. They therefore tend to respond only to those elements of the demands that they consider most vital to protecting their reputation among consumers, ${ }^{32}$ and continue to contest the legitimacy of more extensive demands. Such codes therefore represent only a partial institutionalization of transformative accountability demands, and the principles embodied within the codes then continue to compete for legitimacy with the more radically transformative principles advocated by anti-sweatshop campaigners.

Within this fundamentally contested structure of governance and accountability, labor organizations are faced with two choices. They can support external accountability structures by conducting monitoring of compliance with the codes, thereby strengthening and legitimizing the code-based structures. Or they can continue to work outside the code-based governance system, seeking to delegitimize and further transform it through the ongoing application of transformative accountability claims. This strategic dilemma has generated significant divisions among labor campaigners, with different groups making different judgments regarding which strategies are capable of most effectively empowering workers. Some NGOs and unions have been deeply involved in developing codes (Jenkins, 2001), while others have opposed them vehemently, regarding such schemes as co-optive public relations exercises that threaten to crowd out union and other grassroots participation. In this context of ongoing contestation, in which neither the scope nor the substance of legitimate relationships of power and responsibility have been agreed, external accountability mechanisms remain incapable of offering more than a partial and contested institutionalization of emerging demands for new and transformative forms of public accountability.

\footnotetext{
Such demants commonly refir to measures such as bans on the use of child labor, and health and safey measures to prevent publicly comspicuous aceidents such as mass poisonings and factory tires. These demands for responsibiliry tend to be those based on char temonstration of a diret imposition of ham (commonly considered to be the strongest normative hasts for a clam of responsibility).
} 


\section{The empowering capacity of new agendas of public accountability}

Our interest in these new forms of public accountability extends beyond the desire to understand the dynamics through which they have emerged; it also encompasses a concern for their distributional implications. While practices of public accountability are most commonly evaluated in terms of their role in advancing the agenda of democratic governance, ${ }^{3 ;}$ the goal of this chapter is to evaluate the implications of changing institutions and practices for the well-being of a specific group of disadvantaged actors: workers in the global South. An evaluative framework focusing on the "empowerment" of this particular group of actors enables us to shift our focus away from the conventional concern with empowering a "public," imagined as some kind of coherent or unitary entity, and towards concern for the empowerment of specific disadvantaged individuals and groups within the wider society or public. ${ }^{3.4}$

The concept of empowerment is widely used, but rarely defined rigorously. I define empowerment as an advance in the well-being of a disadvantaged or vulnerable individual or group with respect to their material welfare and/or their agency, where "welfare" refers to the fulfillment of basic material needs, and "agency" is defined as both an individual and a collective concept referring to freedom and capacity to act in pursuit of self-perceived interest. The concept of agency has been employed variously to denote the ability to exercise choice, to participate in social and political processes, and to effect social transformation. ${ }^{37}$ While at times it is helpful to distinguish between different dimensions of "agency," often the achievement of these varying dimensions requires essentially the same sets of capacities: choice, freedom, deliberative, and

33 This is parricularly the case where accountability is examined within discussions ot global governance. See for example Kevhane and $\mathrm{Nyc}$ (2001), Nowell and Bellour

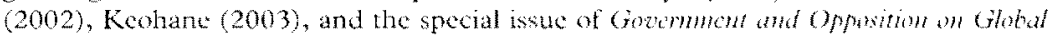
Gowernance and lable Acommability (Spring 2004) 39(2).

" More broadly, this goal is increasingly relewan in the context of a global "puble" that is characterized by pluralism, fragmettation, and often extreme inequality

3 Giddens (1984), Rahman (1984), Rahman (1993), Held (1905), Nelson and Whint (1995), Schneder (1999), Kabeer (2000), and World Bank (200), Sen, tor cximple. uses the term "ageney" in all these ways. He emplews it fo denote truntermational capaciry when he defines an agent as "someone who acts and brings about thange" (Sen, 2001, P. 19), as choted in the context of his discussion of fredom (Dres nud Sen, 2002), and as participation in reterence to policical and social organizacions (Sen, $2001, p .284)$. He cven uses it in a fourth sense, distinguishing for from living standards

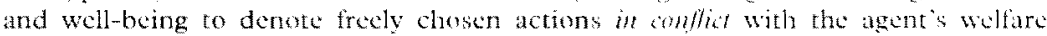
(Saith, 2001). 
critical capacities, and the ability to translate these into action within the external institutional environment. ${ }^{36}$

As applied to workers in the Nicaraguan garment industry, the welfare dimension of empowerment can be understood primarily in terms of income and working conditions. Key indicators of the agency dimension of empowerment include workers' control over their movements within the workplace (such as unconstrained access to the bathrooms or to visit doctors); control over hours worked; freedom to unionize; access to information regarding entitlements and obligations; access to an effective complaints procedure; and the ability to participate in rule-making institutions that affect them, through both direct involvement in shortterm decision-making and the ability to initiate and direct underlying agendas of institutional reform.

How then has the emergence of new forms of global accountability affected the capacity of workers to realize these multiple dimensions of empowerment? From a long-term, industrywide viewpoint, such campaigns have contributed positively to the welfare-related empowerment of Southern gament workers by helping to modify dominant industry norms and practices towards closer compliance with core labor standards. Significant improvements for many workers have been achieved as a result of the dramatic changes in the supply chain management policies of well-known retailers and brands that are most vulnerable to targeting by such campaigns. The changes introduced as a result of prominent campaigns against Nike, Liz Claiborne, the Gap, and Levi iliustrate clearly this process. ${ }^{37}$ The transformation of dominant practices and norms among both consumers and industry players has generated an increasing expectation that brands and retailers should accept responsibility for labor standards within their supply chains (Spar and Burns, 2000). This contributes to greater empowerment at a structural level, since it represents the first steps towards more effectively aligning distributions of responsibilitics with those of regulatory capabilities. However, empowering effects at the factory level, achieved by factorybased campaigns, have been much more limited. In the Chentex case, for txample, the protracted dispute achieved only nominal concessions, most of which have not been sustained. ${ }^{3 \%}$

Fretre (1085), Chambers (1908), Kabeer (2000), Pimbert and Wakeford (2001), Brock and Meriet (2002), and Veneklasen and Miller (2002).

Spar ant Bums (2000) document the case of Nike, which is perhaps the best known of successful activist campaign, producing dramaric changes in supply chain practices.

is In the end, a negoriated settement was reached in which all legal actions were dropped and four union leaders reinstated. However, within a month they had all been forced to 
The partial institutionalization of some elcments of these demands in the form of codes of conduct can also make some contribution to empowerment. As mechanisms of extcrnal accountability, codes provid: a direct institutional means via which evolving norms and practices can be transmitted along supply chains to global production sites. They can also be a powerful coercive mechanism through which norms and practices can be enforced (by the threat to cut off contracts in cases of persistent code violation), thereby facilitating responses to social demands that empower workers. Garment firms unanimously emphasize the importance of complying with codes if contracts with major brands are to be retained.

They have monitors that watch very closely and if you don't fulfill the standards then they take the orders away. If there are always problems then there are no orders. ${ }^{36}$

In the past, the firings of Chentex and the international campaign that followed have meant that now there are more visits and the codes are more severe. The firms are afraid of these, as the contracts can be cancelled if they dont comply. There are different buyers, so a couple of times a month there are inspections, and all the firms are involved in this. "

Evidence from factory owners, investors, and some union representatives also suggests that the imposition of these code-based regimes has led to significant improvements in some basic working conditions, "thereby empowering Nicaraguan workers in terms of core welfare criteria.

They did an inspection in Oetober, and in Fortex and in Sino Nica, they put in many things - fans, comfortable seats, they hung extinguishers in the dining areas, washed the dining area, put out protective masks, put soap and wilet paper in the toilets - a whole heap of things. The Chinese owners don't use these things generally, but the brands have done inspections, and there have been many changes. ${ }^{+2}$

However, the empowering potential of these new accountability practices is significantly limited by the fact that the countervailing power

resign, and there is still no CST (Sandinista) affiliated union operating in the Chentex factory.

* Interview by the author at Nien Hsing head office, Jaipei, 10 March 2004.

"Intervicw by the author with representative of ( $\mathrm{P}^{\prime} \mathrm{l}$ ("management") union, Managua, 2 Decomber 2003.

"1 Evidence from other countries also supports the claim that codes of conduct can lead to improvements in certain aspects of working conditions. Jenkins (2001) for example presented evidence from Victnam, El Salvador, and Honduras showing that concrete improvements have resulted from the imposition of codes.

42 Interview by the author with representative of (S') (Sandinista) union, Managua, 13 December 2003. 
they wield is no longer simply a direct counterbalance to primary sources of power, as envisaged within the binary state-centered accountability systen; rather, such forms of accountability have entailed the diffusion of power between actors, and the emergence of an increasingly fragmented and multilayered distribution of power. Within this pluralistic structure, firms exercise power over workers, information flows from workers through NGOs to consumers, and consumers (together with broader social actors in the global North) may then impose sanctions upon firms. ${ }^{+3}$ Mechanisms of power, countervailing power, information transmission, and sanctioning are thus becoming more fragmented, functionally disaggregated, and diffuse. Increasingly, outcomes are determined not within centralized and privileged sites of political power, but as the product of interactions between multiple layers of actors: states, firms, consumers, and a range of non-state actors spanning multiple levels of transnational production structures. In this context, a demand to "hold powerful actors accountable for their actions" does not necessarily translate into an outcome in which powerholders are held accountable to those affected. The emergence of what is effectively a whole new category of "intermediaries" within accountability relationships creates two related problems.

First, there is an implicit conflation of those subject to power and those demanding accountability, so that power relations between those impacted by the primary source of power and those making accountability claims are often obscured, and these secondary power relations between intermediaries and workers are not themselves constrained by effective accountability mechanisms. This problem is clearly illustrated by the power dynamics that emerged during the Chentex factory campaign within the non-state networks through which transformative accountability demands were advanced. Although solidarity campaigns are nominally driven from the bottom up, campaign structure tends to reflect the structure of global production chains. Accordingly, the "transnational advocacy networks" through which many of these campaigns are conducted themselves embody asymmetric power relations in which it is often Northern participants rather than workers themselves who play the dominant decision-making roles. The most powerful sources of leverage over US brands, consumers, and government are concentrated in the hands of US members of the network, since it is they

"These new geographies of power then interact with binary structures of power and accountability that continue to operate (albeit in more limired ways) within statecentered gosemance systerns located in ach territory participating in the global production thain. 
who can most easily access these sites of power, and they possess disproportionate access to financial resources and communication technology. Power is also exercised asymmetrically in the initial construction of network membership, as the disproportionate ability of Northern participants to control network membership gives them significant discretionary power to decide which local groups to include and which to exclude, leaving little scope for conflicting voices at the local level to be mediated within the processes of forming campaign goals and strategies.

Despite the significant degree of power wielded by Northern actors within these networks, such actors are generally not accountable to workers for the way this power is exercised. "The lack of accountability to workers whose "stories" are being deployed as weapons has meant that campaign design has often failed to give top priority to the direct interests of the workers immediately involved, which significantly reduces the potential of such campaigns to empower workers. Indeed, some anti-sweatshop campaigns have generated outcomes that have caused direct harm to significant numbers of workers. The screening on US and Nicaraguan television in 1997 of the Hard Copy program "exposing" sweatshop conditions in Nicaraguan garment factories was followed by the firing of workers directly involved with the program, job losses due to the cancellation of some contracts by targeted firms, and the firing of hundreds of workers under eighteen (despite the labor code allowing workers from the age of fourteen) as firms attempted to avoid the charge of using child labor. ${ }^{45}$

This failure to appropriately distinguish the interests and preferences of workers from those of the Northern actors dominating the campaigns creates a second, closely related problem as accountability relations between companies and their critics begin to be institutionalized within structures of external accountability such as codes of conduct. In many cases, external accountability mechanisms are constructed between inappropriate sets of actors, as firms are made accountable to Northern NGOs, consumers, and "independent" monitors rather than directly to affected workers themselves; this problem is reflected clearly in many of the discourses surrounding codes of conduct. The World Bank, for instance, explicitly uses the language of external accountability in explaining the emergence and functioning of corporate codes of conduct, but its only mention of individual workers and their families - who are those most directly affected by such codes - is under the label of

it This is a similar point to that mate by Konane (2002) when he refers to a distonneer beween logitimacy and accourability.

${ }^{15}$ See www nicanct org/115laborpand, homl. 
"organized labor," despite the majority of global garment workers not being organized in any way:

External stakeholders, including students, human rights organizations, organized labor, religious institutions, consumer advocates, universities, representatives of local, state and federal governments around the world, and the Secretary General of the UN hove demanded greater transparency and accountability by corporate institutions with respect to business decisions that have a social and environmental impact... corporate leaders have recognised that the success of their brands is ticd to whether their business is conducted in a manner acceptable to those affected by it. (Wonld Bank, 2003, p. 1)

Even this reference is buried in a long list of external stakeholders from the global North, the majority of whom are those participating in accountability relations through their role in information transmission and sanctioning, rather than as those affected by corporate decisions. The disappearance from the picture of those who are supposedly the ultimate "principals" of these new structures of "external" accountability has significantly undermined the effectiveness with which such codes have empowered Southern workers. This appears to be due primarily to the multiple ways in which the exclusion of workers from these structures has weakened code enforcement. Significant barriers to the participation of workers and their organizations in monitoring code enforcement include the absence of adequate formal consultation processes within the inspection process, the absence of complaints procedures, a failure to effectively inform workers about code content, ${ }^{46}$ and the extreme lack of transparency regarding monitoring procedures and findings. ${ }^{77}$ In part as a result of such weaknesses, Nicaraguan workers speaking with Prieto and Bendell (2002, p.7) claimed that the codes "are for decoration, as the workers don't see them being implemented." The lack of accountability to workers within the processes through which codes are initially formulated further undermines their empowering potential, as the formation of codes is driven primarily by a perceived need to be accountable to consumers. This has resulted in codes being driven by top-down consumer-focused agendas, thus producing a disproportionate emphasis on issues - such as underage labor - that have a high profile among Western consumers and are therefore considered by firms to be the most potentially damaging (Jenkins,

Source: autwor"s discussion with Nitaraguan factory workers at MEC: workshop, 23 Norember 2003.

Target, for example, dams that "Ihe procedures used by our Comprate Compliance area are consideted proprictary," personal communication, Target Guese Relations, 38 Natember 2003 . It is also very nure for the content of monitoring reports to be reveated either to workers or to the wider public. 
2001). This focus often comes at the expense of issues identified by workers themselves as higher priorities. ${ }^{16}$

\section{Conclusions: new forms of accountability and the empowerment of Southern workers - from transformative to plurilateral accountability}

The emergence within transnational supply chains of these new agendas of public accountability has already produced substantial changes within targeted transnational production chains. The impact of these changes thus far suggests that they have significant potential to further advance the empowerment of Southern workers within the governance structures of the global economy. However, these agendas remain limited by the per"sistence of binary discourses of accountability, which are no longer appropriate within an environment increasingly characterized by pluralistic structures of power. As described above, a binary view of accountability results in the implicit conflation of those actors who are subject to power with those who are demanding accountability, which significantly constrains the capacity of existing accountability mechanisms to empower Southern workers. In order to entrench principles of empowerment at a structural level within a transformed global governance system, and thus to provide a systemic basis of countervailing power for Southern workers, there is a need for some far-reaching changes in how we conceptualize public accountability structures and their relationship to the ordering of publicly relevant power. This will entail moving from the distorted and contested structures of transformative and external accountability to a reconstructed governance system in which accountability structures can once again function to legitimize and reproduce systemic power distributions through a stable set of reconstituted principles. To enable these changes, new forms of institutional innovation will be required.

I argue that such innovations should be based on a central principle of "plurilateral" accountability: that is, pluralistic structures of account-ability that mirror and equilibrate the pluralistic distributions of power within the prevailing governance system. "Concepts of "plurilateralism"

18 Workers intervicwed by Pricto and Bendell $(2002, \mathrm{p} .8)$ reported a number of their priorities o differ from those appearing in official corporate codes Commonly mentioned concerns included health and safwy issues related to pregnancy, transport home from work, and restrictions on overtime which seme workers sonsidered inappropriate given the insufficiancy of their standard wages.

th The case for the development of plurilateral mechanisms of accountabiter rests primarily upon imshational arguments, which must be separated from the normative encerns I rased above in relation to consepts at external acountability the 
and "hybridity" are commonly deployed in the analysis of structures of global governance (Cerny, 1993; Vayrynen, 2003), but little attention has been given to how we might construct parallel pluralistic structures within our discourses and institutions of accountability. To this end, I suggest that it is helpful to imagine a plurilateral system of governance and accountability that is structured according to the central principle of "complex reciprocity." Instead of dichotomizing governors and the governed (or agents and principals), and simply holding the former accountable to the latter, such a system would be characterized by a lavered, horizontal structure in which each category of actors, performing disaggregated functions and exercising differentiated forms of power, is held accountable to each other, supporting the emergence of a systemwide equilibration of power and responsibility.

The idea of a plurilateral accountability structure implies a radical change in how we conceptualize accountability - more so than would occur simply by moving from a single binary accountability relationship between a state and a public to a seriality of vertical and binary relationships in which each agent is linked to an expanding number of external principals. Although the idea of "complex reciprocity" may appear largely consistent with many features of an accountability structure comprised of serial binary relations, it has been demonstrated above that the ongoing dominance of such binary discourses appears to be supporting significant distortions within emerging institutions of external accountability. These distortions are undermining the capacity of these institutions to empower Southern workers, which means that there is a practical as well as a theoretical imperative to consider more seriously how we might progress from the binary structures of "external" accountability towards the construction of a balanced, plurilateral system of public governance and accountability.

It is beyond the scope of this chapter to speculate in depth about specific institutions via which the central principle of plurilateral accountability could be materially entrenched. However, building from the central principle of re-articulating power and responsibility by means of a systemic structure of complex reciprocity, it is possible to suggest several key features that such an accountability system would need to embody, in order to empower Southern workers most effectively. Considering each major category of systemic actor in turn, fims should be

development of an effective and legitimate system of plurilateral accountability would reyuire not only the development of workable institutional mechanisms, but also the specification of an agreed set of normative principles to define the legitimate relationship between power and responsibility. 
held accountable through structures of information transmission that are linked directly to workers, and that are backed up by sanctions imposed at overlapping levels by consuming and producing states, by $\mathrm{NGOs}$, and by consumers. ${ }^{50}$ At the same time, states need to be hold accountable not only to NGOs, workers, firms, and consumers within their own territory, but also to workers and other stakeholders located outside these physical boundaries. Non-state actors within the transnational networks that promote agendas of transformative accountability must themselves become more accountable to the workers whose interests they claim to represent, through the construction of more durable and accountable network structures and more effective engagement with the range of competing views at the local level during the process of constructing network membership.

Currently, the global garment industry remains characterized by governance structures in which key decisions affecting Southern workers are controlled by Northern brands and retailers, and by the governments and populations of the countries in which these powerful Northern actors are located. The transformative accountability agendas that are being pursued by transnational networks of non-state actors have achieved some initial progress towards placing countervailing power in the hands of Southern workers and their supporters, and external accountability initiatives have partially institutionalized the core principles of this transformative agenda. However, a new agenda of "plurilateral accountability" must now be developed and implemented to enable core principles of empowerment to be more effectively embedded within the institutional system that governs global production, in which Southern workers play such a fundamental role.

\section{References}

Braithwaite, J. and P. Drahos (2000) Global Bnimess Rugnlation. Cambridge University Press.

Brock, K. and R. McGec (2002) Kwowing Pormy: Cittical Reflections on Participatory Research and Policy. London: Earthscan.

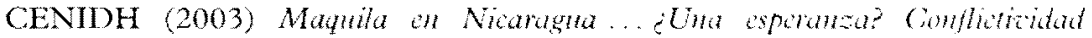
laboral en la maquila: nit andists desde la prictica do les dowhos hamanes. Managua: Centro Nicaragüense de Derechos Humanos.

sat Different actors are able to impose sanctons of diforenc kinds. Sanctions imposed by consumers and NGOs are able to distingush more effectively between fims, thus supporting offorts of industry leaders to expand the boundmies af socially responsblo best-practice, while state sanctions based on the unform imposition it nimimum standards are particularly important for regulating the conduce of "laggards." Overlapping layers of sanctions can thus be complementary, providing grater flexibility" and strengen to the accountability system as a whole. 
Corny, P. G. (1993) "Plurilateralism: Structural Differentiation and Functional Conflict in the Post Cold War Order," Millenimu: Foumal of Intemational Sulties $22(1), 27-51$.

Chambers, R. (1998) "Paradigm Shifts and the Practice of Participatory Research and Development," in I. Guijt and M. K. Shah (eds.) The Myth of Commmitu: Gendor lssues in Participatory Dewelopment. London: Intermediate Technology Publications.

Cutler, A.C. (2002) "Private International Regimes and Interfirm Cooperation," in R. B. Hall and T. I. Biersteker (eds.) The Emargence of Priate Awhorty in Global Gowemance. Cambridge University Press.

Detomasi, D. (2002) "International Institutions and the Case for Corporate Governance: "Toward a Distributive Governance Framework?," Global Givanate 8(4), 421-42.

Drize, J. and A.K. Sen (2002) India: Development and Participation. Oxford University Press.

Elliott, K.A. and R. B. Freeman (2000) "White Hats or Don Quixotes? Human Rights Vigilantes in the Global Economy," NBER Conference on Emerging Iabor Market Institutions. At http:/papers.nber.org/papers/W8102.

Freire, P. (1985) Pedagogy of the Oppressed. Harmondsworth: Penguin.

Gereffi, G. (1099) "A Commodity Chains Framework for Analyzing Global Industries." Available at www,ids.ac.uk/ids/global/valchn.htmi.

Giddens, A. (1984) The Comstitution of Soctety: Outline of the Theory of Struturation. Cambridge: Polity.

Goetz, A.M. and R. Jenkins (2002) "Voice, Accountability and Human Development: The Emergence of a New Agenda," Background paper for the Human Development Report 2002 ("Voice and Accountability") (Paper prepared for the mecting of the UNDP HDR Advisory Panel, 5-7 November 2001).

Harrison, A. and J. Scorse (2003) "The Impact of Globalisation on Compliance with 1 abor Standards: A Plant-level Study," Paper presented at Brookings Trado Forum.

Hautler, V. (2001) A Publi Role for the Prioate Sutor: Industry Self-Regulation in a Global Ecomomi. Washington, DC: Carnegie Endowment for International Pace.

Held, D. (2004) "Democratic Accountability and Political Effectiveness from a Cosmopolitan Perspective," Govermmont and Opposition 39(2), 364-91.

Held, D. (2000) "Regulating Globalization? The Reinvention of Politics,"

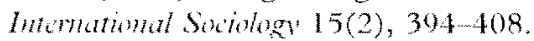

Held, D. (1905) Damoraly and the Global Order: From the Moden State to Cosmopolitan Gomemana: Cambridge: Polity.

Jenkins, R. O. (2001) Comporate Gotes of Conduct: Solf-regulatint in a Global Leomomy. Geneva: UNSRID.

Kabeer, N. (2000) Discusing Womon's Impowenment Theory and Practice. Stockholm: Swedish International Development Cooperation Agency.

Keohane, R.O. (2003) "Global (iovernance and Democratic Accountability," in D. Held and M. Koenig-Archibugi (eds.) Taming Globalization: Hrontiers of Germance. Cambridge: Polity. 
Keohane, R.O. (2002) "Global Governance and Democratic Accountability." Available at www poliduke.edu/people/Faculty/docs/millpaper.pdt.

Keohane, R. O. and J. S. Nye (2001) "Democracy, Acoountability and Global Governance," available at www.ksg.harvard.edu/prg/nye/ggaiune,pdf,

Koenig-Archibugi, M. (2004) "Transnational Corporations and Public Accountability," Gozmment and Opposition 39(2), $234-59$.

Lipschutz, R. D. and C. Fogel (2002) "Regulation for the Rest of Ls? Global Civil Society and the Privatisation of Transnational Regulation," in R. B.

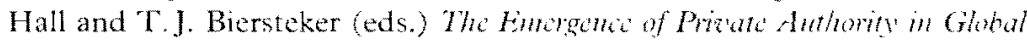
Gownonte. Cambridge University Press.

Macdonald, K. (2004) "Emerging institutions of Non-state Governance within Transnational Supply Chains: A Global Agenda for Fimpowering Southern Workers?" American Political Science Association, Chicago, 2-5 September.

Mendez, J.B. and R. Koepke (2001) Mupres y Manila. Resphesta a la

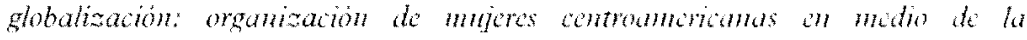

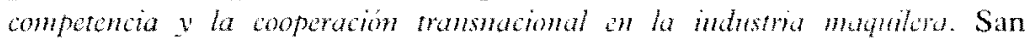
Salvador: Fundación Heinrich Böll.

Nee, G. (2002) "The Political-Economic Analysis of the Nien Hsing/Chentex Campaign," in Y.C. Chen and M. Wong (cds.) Now Bondagr and Old Resistance: Realitics and Challenges of the Labow Moremem in Tarwan. Hong Kong: Hong Kong Christian Industrial Committed.

Nelson, N. and S. Wright (1995) "Participation and Power," in N. Nelson and S. Wright (eds.) Power and Panticipatory Derdopmont Them and Patict. London: Intermediate Technology Publications.

Newell, P. and S. Bellour (2002) "Mapping Accountability: Origins, Contexts and Implications for Development," IDS Working Paper 168. Sussex: Institute of Development Studies.

Pimbert, M. and T. Wakeford (2001) "Overview - Deliberative Democracy and Citizen Empowerment," in M. Pimbert and 'T. Wakeford (cds.) Dehboutice Domocracy and Gitizen Emporooment, PLA Notss 40. I, ondon: International Institute for Environment and Development.

Prieto, M. and J. Bendell (2002) If von Want to Holp ws then Stan Listining to ws.' From Factories and Plantations in Contral Amevica, Womm Spuk ont about Comporate Rexpomibilify. Bristol: New Acadeny of Business.

Rahman, M.A. (1993) Pople's Solf-dectopmotr: Persections on Paticipatory Action Rescarch: A foumcy through Lxperichic. London: Zed Books.

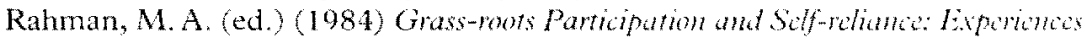
in South and Souh East Asia. New Delhi: Oxford and IBH in collaboration with Socicty for Participatory Research in Asia.

Rosenau, J.N. (2000) "Governance in a Globalizing World," in D. Held and A. G. McGrew (eds.) The Global Transfomations Reater: An Introdiction to the Globalisation Dubate. Cambridge: Polity.

Roscnau, J. N. (1992) "Governance, Order and Change in World Politics," in J. N. Rosenau and E.O. Czempiel (cds.) Gonemance whomt Gowmment: Order and Change in World Politics. Cambridge University Press.

Ruggie, J. G. (2001) "global governancenet: The Global Compact as Learning Network," Global Gowemante 7, 371-8. 
Suith, R. (2001) "Capabilities: The Concept and its Operationalisation," QEH Working Paper Series (No.60).

Schneider, 11. (1909) "Participatory Governance for Poverty Reduction,"

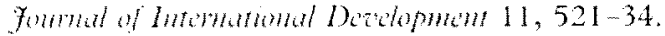

Scholk, 1.A. (2002) "Ciril Sociery and Democracy in Global Governance,"

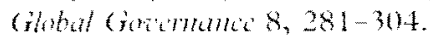

Sen, A.K. (2001) Detopmin as lowedom. Oxford University Press.

Smouts, M.-C. (1998) "The Proper Use of Governance in International Relations," Imomational Social Setonce formal 50(155), 81-9.

Spar, D. and J. Borns (2000) Hinimg the Wall: Nike and Intemational Labor Pathas. Buston: Harvard Business School.

Stoker, G. (1998) "Covernance as Theory: live Propositions," Imternational Soud Sivme folmal $50(155), 17-28$.

Strange, S. (2000) "The Declining Authority of States," in D. Held and A. G. MeCrew (ods.) The Glohal Transformations Reader: An Intaduction to the Ghobliation Debate. Cambridge: Polity.

Tsogas, G. (2001) Labor Regrtatim in a Global Economy. New York: M. E. Sharpe.

Vayryen, R. (2003) "Political Power, Accountability and Global Governance," Paper prepared for the Joint Sessions of the European Consortium for Political Research, Edinburgh.

Vencklasen, 1. and V. Miller (2002) A Newe Weave of Power, People and Politics: The Acthn Givd for Adrocaly and Gitian Paticipation. Oklahoma City: World Neightors.

Woods, N. (2002) "Accountability in Global Covernance," Background paper for the Human Development Report 2002 (Occasional Paper 2002/21).

Woods, N. (2000) "Accountability, Governance and Reform in the International Financial Institutions," available at www.g24,org/woods.pdf.

World Bank (2003) Company Codes of Conduct and Intenational Standards: An Allathik Compamion. Washington, DC: World Bank.

World Bank (2002) Empontment and Poonty Reduction: A Sourcbook. Washington, DC: World Bank. 


\section{University Library}

\section{- M M N E R VA A gateway to Melbourne's research publications}

Minerva Access is the Institutional Repository of The University of Melbourne

Author/s:

Macdonald, $\mathrm{K}$

Title:

Public accountability within transnational supply chains: a global agenda for empowering Southern workers?

Date:

2007-01-01

Citation:

Macdonald, K. (2007). Public accountability within transnational supply chains: a global agenda for empowering Southern workers?. Ebrahim, A (Ed.). Weisband, E (Ed.). GLOBAL ACCOUNTABILITIES: PARTICIPATION, PLURALISM, AND PUBLIC ETHICS, (1), pp.252-279. CAMBRIDGE UNIV PRESS.

Persistent Link:

http://hdl.handle.net/11343/32024 